\title{
MICROSTRUCTURAL AND RHEOLOGICAL PROPERTIES OF IRRADIATED RICE
}

\author{
Propriedades microestrutural e reológica de arroz irradiado
}

\author{
Ívina Catarina de Oliveira Guimarães ${ }^{1}$, Joelma Pereira ${ }^{2}$, Vanda Maria de Oliveira Cornélio ${ }^{3}$, \\ Luiz Roberto Batista ${ }^{2}$, Eric Batista Ferreira ${ }^{4}$
}

\begin{abstract}
The culinary quality of rice directly results in its market value and consumer acceptance. Thus, the present study evaluated the effect of gamma irradiation on the properties of the polished white rice starch, as well as their characteristic pulp. Doses of 6.5 $\mathrm{kGy}$ and $7.5 \mathrm{kGy}$ did not alter the microstructure of rice starch granules, but interfered with rheological properties when compared to the control treatment, resulting in a reduction of the maximum and final viscosity and retrogradation. Since the microstructural and rheological properties within the values associated with rice quality, it was inferred that gamma irradiation did not alter the decisive characteristics for the acceptability of this cereal.
\end{abstract}

Index terms: Free radical, paste characteristics, food irradiation.

\section{RESUMO}

A qualidade culinária do arroz resulta diretamente em seu valor de mercado e aceitação do consumidor. Assim, no presente estudo, avaliou-se o efeito da irradiação gama sobre as propriedades do amido do arroz branco polido, bem como na sua característica de pasta. Doses de 6,5 kGy e 7,5 kGy não alteraram a microestrutura dos grânulos de amido de arroz, mas interferiram nas propriedades reológicas quando comparado ao tratamento controle, resultando na redução da viscosidade máxima e final; e retrogradação. Esse resultado pode estar correlacionado à presença de radicais livres no arroz branco polido recém-irradiado, os quais se estabilizaram ao passar quatro meses. Desde que as propriedades microestruturais e reológicas se encontrem dentro dos valores associados à qualidade do arroz, a irradiação gama não altera as características determinantes para a aceitação do cereal.

Termos para Indexação: Radical livre, características de pasta, irradiação de alimentos.

(Received in november 30, 2012 and approved in april 1, 2013)

\section{INTRODUCTION}

The effect of the gamma irradiation on the chemical composition of starch products has been receiving the researcher attention (AQUINO; NUNES; CORRÊA, 2011; LEE et al., 2007). The irradiation is considered one of the starch physical modification methods, because the ionizing energy quickly penetrates inside the granule of that polysaccharide, being able to cause greater damage to its structure (BAO; BAO; JANE, 2005; Han; Lim, 2012).

As a main ingredient of many cereals, the starch supplies their structure, texture and consistency. The starch granules are semicrystalline structures composed of macromolecules arranged in a radial direction. The macromolecules form hydrogen bonds which results in the emergence of crystalline areas or micelles. They are the crystalline areas of the starch that maintain the granule structure, control its behavior in the presence of water and they make the granules more or less resistant to chemical and enzymatic attack (GALLANT; BOUCHET; BADWIN, 1997).

The intact starch granules are not soluble in cold water, but they can retain small amounts of water in a reversible way, causing a small swelling. When the temperature increases, the starch molecules vibrate vigorously, breaking the intermolecular bonds and allowing the formation of hydrogen-water bonds. The water penetration and the progressive separation of larger starch chain segments increase the structure at random and reduce the number of crystalline areas. The continuous heating in the presence of abundant water results in the complete loss of crystallinity. The moment in which the birefringence disappears is known as 'the point' or gelification

1Universidade Federal de Lavras/UFLA - Departamento Ciência dos Alimentos/DCA - Cx. P. 3037- 37200-000 - Lavras- MG - Brasil ivina@dca.ufla.br

¿Universidade Federal de Lavras/UFLA - Departamento Ciência dos Alimentos/DCA - Lavras- MG - Brasil

${ }^{3}$ Empresa de Pesquisa Agropecuária de Minas Gerais/EPAMIG - Centro tecnológico do Sul de Minas/CTSM - Lavras - MG - Brasil

${ }^{4}$ Universidade Federal de Alfenas/UNIFAL - Departamento de Ciências Exatas - Alfenas - MG - Brasil

Ciênc. agrotec., Lavras, v. 37, n. 3, p. 237-243, maio/jun., 2013 
temperature that, usually, is produced within a temperature range, first gelifying the larger granules and, last, the smallest (VITTI, 1996).

Therefore, an important variable in the technological quality of rice concerns the gelatinization temperature, which is a property of the starch related to the time necessary for cooking. It is measured by the temperature in the which $90 \%$ of the starch granules are gelatinized or irreversibly swollen in the hot water, varying from $55^{\circ} \mathrm{C}$ to $79^{\circ} \mathrm{C}$. When a rice cultivar presents a high gelatinization temperature, that means that its grains require more water and cooking time, while under intermediate (the national preference) and low temperatures, the gelatinization temperature require less time and water for cooking (BASSINELLO; ROCHA; COBUCCI, 2004).

Some studies report the interference of gamma irradiation on the technological properties of rice, such as Sirisoontaralak and Noomhorm (2006), who observed that irradiation of aromatic rice caused a decrease in certain properties of pulp, increased absorption of water and the solids content in cooking water. Besides these, there was an intensification ofyellow, and decrease in hardness of the cooked rice. The effect of irradiation on the microstructure of the inner endosperm was larger than the outer endosperm. Parameters of RVA (Rapid Visco Analyser) were decreased with increasing dose, due to the breaking of the starch granules caused by irradiation. Hana and Lim (2012) observed that when the starches from waxy rice were irradiated a significant decrease in pasting viscosity was found with an increase in irradiation dose, indicating the presence of chain degradation induced by the radiation. Treating at higher doses decreased the emulsion capacity and stability of the starches.

In order to deepen the knowledge regarding gamma irradiation on rice quality, the present study sought to evaluate the effect of gamma irradiation on the properties of rice starch, as well as its paste characteristics.

\section{MATERIAL AND METHODS}

\subsection{Sample}

Seven commercial samples of polished long grain fine white rice, type 1 , contained in a $2 \mathrm{~kg}$ package and that were received in perfect state of physical integrity and within the validity periods were used in the present research.

\subsection{Irradiation process and conditioning of samples}

Each rice sample was homogenized and fractional in three $500 \mathrm{~g}$ subsamples, two of them destined to the different irradiation doses under study and the other used as control (no-irradiated). All of the samples were conditioned in plastic polyethylene packaging, properly sealed and identified, providing more uniform conditions during the irradiation process.

The irradiation of the rice samples was conducted at Gamma Irradiation Laboratory (GIL) of the Nuclear Technology Development Center (NTDC), using an Gammacell GB-127, GO-214 (MDS Nordion, Canada) irradiador with a cobalt source (Co60). The doses employed in the process were $0 \mathrm{kGY}$ (control), $6.5 \mathrm{kGy}$ and $7.5 \mathrm{kGy}$. The radiation doses were chosen for having been significant in the reduction of the fungal population in rice, in a preliminary survey. The dose rate used in this study was $6.0 \mathrm{kGy} /$ hour. The temperature conditions were maintained at $25 \pm 3^{\circ} \mathrm{C}$, before, during and after the irradiation process.

\subsection{Water activity (aw)}

For the determination of the water activity, the AquaLab, Model CX-2 (Decagon Devices Inc., USA) digital apparatus was used, with controlled temperature readings at $25 \pm 0.3^{\circ} \mathrm{C}$.

\subsection{X-ray diffractometry}

The x-ray diffractograms were obtained using a DMax (Rigaku, Japan) diffractometer equipped with a cobalt tube (radiation Co-K $\alpha, \gamma=1.79026 \AA$ ), with a curved crystal graphite diffracted beam monochromator, operating with a potential difference of $40 \mathrm{kV}$ and electric current of $30 \mathrm{~mA}$. The relative crystallinity of the starches was determined tracing a line on the base of the main peaks on the diffractogram.

\subsection{Electron paramagnetic resonance (EPR)}

To evaluate the use of the EPR technique in the detection of the irradiated rice, before the free radical quantitative determination, three samples of polished white rice recently-irradiated and three samples irradiated four months previously were introduced in $0.2 \times 10.0 \mathrm{~mm}$ quartz tubes, to be analyzed by EPR. The EPR spectra were recorded at room temperature, in a spectrometer equipped with a cylindrical cavity (Bruker) that operates in the microwave frequency range of $9.4 \mathrm{GHz}$ (Varian) and $100 \mathrm{kHz}$ magnetic field modulation.

\subsection{Paste characteristics}

The viscosity profile of the triturated polished white rice was evaluated in a Rapid Visco Analyser, series 4 apparatus (RVA; Newport Scientific Pty Ltd, Sidney, Australia), at the concentration of $3.0 \mathrm{~g} 25 \mathrm{ml}^{-1}$ of water. For the calculation of this concentration, sample and water 
amount corrections were made, according to the table supplied by the manufacturer. To conduct the evaluation, the Std 1 (Standard Analysis 1) programming was used, of the Thermocline for Windows version 3.06 software. The results were interpreted based on graphs plotted by the program.

\subsection{Microstructure of starch granules}

For the visualization of the rice starch granule microstruture, slides containing a drop of the water, glycerol (1:1) aqueous dispersion and starch, covered with a coverslip were prepared. The addition of the glycerol had the purpose of reducing the brownian motion of the sample. The images were obtained in an Olympus BX 51-p microscope fitted with an Olympus U-POT polarizing filter system and an Olympus C5060-ADU photomicrograph system (Olympus América Inc., New York, USA), with 1,000 $\mathrm{X}$ amplification.

\subsection{Analysis of results}

The variables were studied considering the completely randomized experimental design (CRD) and the data obtained were statistically analyzed, through variance analysis (ANOVA) and mutually orthogonal contrasts, establishing the minimum level of significance at $5 \%(\mathrm{p}<$ 0.05 ). The software was used $\mathrm{R}$ (R Core Team, version 2.15.0, 2012).

\section{RESULTS AND DISCUSSION}

\subsection{Water activity}

In the present study, the water activity of the polished white rice was not altered with the use of the gamma irradiation (Co60) and the average value (0.60) presented by the analyzed grains fell within the parameters appropriate for their conservation and quality.

\subsection{X-ray diffraction}

The starch granules, for being partially crystalline, provide specific $\mathrm{X}$ - ray diffraction patterns. The development of the crystallinity in a polymer is dependent of its structural regularity and the factors that affect this crystallinity include polarity, hydrogen bond presence, as well as the "packing" capacity of the polymeric chains (FRANCO et al., 2002). As a result, the starch granules can correspond to two polyforms (A or B) or to an intermediate form (C), which have their classification based on variations of the water content and the double helix packing configuration (IMBERTY, 1991).

Figure 1 represents the characteristic diffractogram found for all of the samples of polished white rice of the present study, obtained through an x-ray dispersal spectrum with diffracted radiation intensity as a function of the Bragg angle $(2 \theta)$.

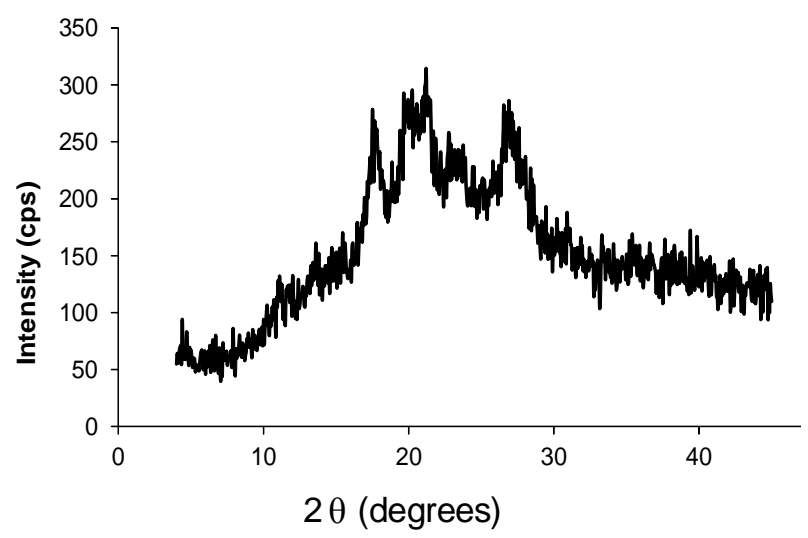

Figure 1 - X-ray diffractogram of polished white rice as a function of $2 \theta$.

In a general way, for all of the polished white rice samples analyzed, the starch presentd three diffraction peaks $\left(2 \theta=17.5^{\circ} ; 21.2^{\circ} ; 26.5^{\circ}\right)$ and intensities of $278 \mathrm{cps}$, $314 \mathrm{cps}$ and 286cps, respectively, as is observed in Figure 1 , thus confirming the presence of crystalline domains in its structure, typical of an A type diffractogram found for cereals, according to the literature (FRANCO et al., 2002).

The crystallinity type A occurs in most of the cereals (corn, rice, wheat, oats) and it is described as a highly condensed and crystalline monocyclic cellular unit, in which twelve glucose residues of two chains in the counterclockwise position shelter four water molecules between the helices (OATES, 1997; ELIASSON, 2004). According to Li, Vasanthan and Rossnagel (2004), the starches with A type crystallinity are more prone to hydrolysis due to the presence of surface pores that can be enlarged by enzymatic action, facilitating its action within the granule.

Chung and Liu (2010) observed a decrease in the relative crystallinity of potato and bean starches after ãirradiation at $50 \mathrm{kGy}$.

\subsection{Electron paramagnetic resonance - EPR}

The interest in knowing if a food has been irradiated or not is primarily due to the consumer right to have knowledge concerning what they are acquiring.

The concentration of free radicals in a sample, generated or not by irradiation, can be determined from 
the intensity of the EPR signal (SCHREIBER et al., 1993).

In the present work the typical free radical signal was only visualized in the recently-irradiated samples, with the signal amplitude increased with the use of higher radiation doses. According to Leal et al. (2004), EPR can contribute to the detection of irradiation in different foods groups.

EPR as a method for detection of food is irradiated based on the life long as the signals of these radicals can be detected months after irradiation in products such as spices, nuts, animal bones (DESROSIER, 1996). The present study did not detect free radicals in the samples of polished white rice irradiated four months previously. This observation can be justified by the fact that the free radicals tend to react quickly with several molecules, atoms or whole compounds, seeking stability and, therefore, presenting a quite short duration (BIANCHI; ANTUNES, 1999).

Some types of non-irradiated foods, such as french fries and instantant pasta, contain measurable amounts of unpaired electrons and paramagnetic transition metals ions. Thus, the more presence of free radicals can be related to the vegetable product and to its origin, species, variety, cultivation soil, application, or not, of agricultural pesticides, processing type employed, manipulation, as well as the interaction of the constituents themselves(DESROSIERS, 1996).

\subsection{Paste Characteristics}

The viscoelastograph profiles of the nonirradiated and irradiated polished white rice samples, appraised by the Rapid Visco Analyser (RVA), are presented in figure 2 .

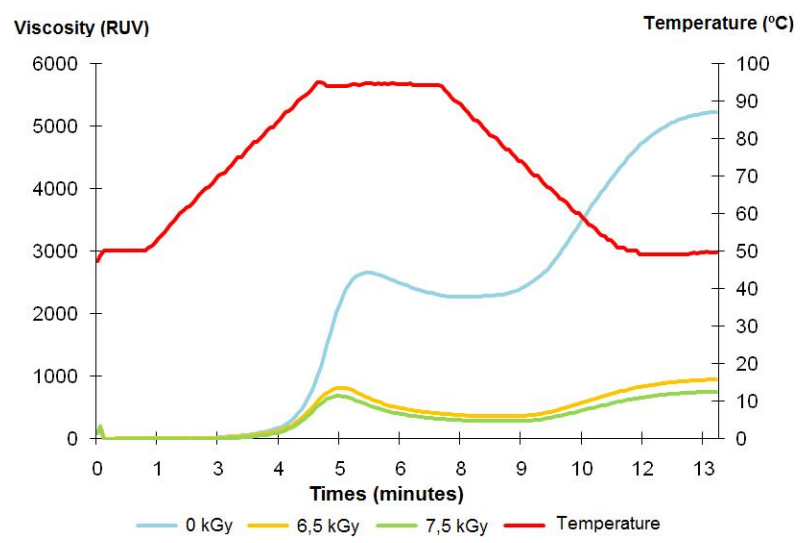

Figure 2 - Viscoelastograph profiles, measured by a Rapid Visco Analyzer $\left(3 \mathrm{~g} \mathrm{ml}^{-1}\right)$, of polished white rice without irradiation $(0 \mathrm{kGy})$ and with irradiation at $6.5 \mathrm{kGy}$ and $7.5 \mathrm{kGy}$.
The gamma irradiation (Co60) provoked intense alterations in the starch of the polished white rice, modifying its behavior profile when the suspension was submitted to temperature alterations and mechanical agitation. The viscosity curves presented more intense reduction with the use of higher radiation doses. The values regarding the properties of the polished white rice paste submitted to different radiation doses ( $0 \mathrm{kGy}, 6.5 \mathrm{kGy}$ and $7.5 \mathrm{kGy}$ ), obtained from the elastographs, are presented in table 1.

All the polished white rice starch paste characteristics altered in function of their exposure to the gamma radiation (Co60). This was attributed to the decrease in degree of polymerization of ã-irradiated starch, due to the breakage of starch chains, inducing the reduction in paste viscosity (LIU; YING; XUE, 2012).

Among the rheological alterations caused by the gradual increase of the gamma radiation doses, the decrease of the maximum and final viscosity stands out, a fact also reported by authors who studied irradiated rice paste characteristics correlated to the short cooking time (ZANÃO et al., 2009; YU; WANG, 2007; SIRISSONTARALAK; NOOMHORM, 2006; BAO; BAO; JANE, 2005).

According to the justification of Yu and Wang (2007), the gamma radiation can generate free radicals in the starch macromolecules, which are capable of hydrolyzing chemical bonds and, in doing so, break large molecules into small dextrin fragments, altering their structure and, consequently, their functionality.

The initial paste temperature indicates the minimum temperature necessary for the cooking of a specific sample, which can have implications for the stability of other components present in a formulation, such as affecting the energy to be consumed in this process (ELIASSON, 2004). As a result, variations in that parameter can alter the food quality, as well as the cost of energy spent in the processes. In the present study, it could be observed that the initial paste temperature of the polished white rice $\left(83.32^{\circ} \mathrm{C}\right.$ for $0 \mathrm{kGy}, 84.96^{\circ} \mathrm{C}$ for $6.5 \mathrm{kGy}$ and $85.41^{\circ} \mathrm{C}$ for $7.5 \mathrm{kGy}$ ) presented tiny alterations with exposure to the radiation, indicating a favorable aspect to the use of this treatment. Zanão et al. (2009) found opposite results in his study: the irradiated rice paste temperature decreased with doses of $1.0 \mathrm{kGy}, 3.0$ $\mathrm{kGy}$ and $5.0 \mathrm{kGy}$.

Another fact to be considered was the gradual decrease of the time to reach maximum viscosity with the increase of the radiation dose (5.77 minutes in 0kGy, 5.17

Ciênc. agrotec., Lavras, v. 37, n. 3, p. 237-243, maio/jun., 2013 
minutes in $6.5 \mathrm{kGy}$ and 5.12 minutes in $7.5 \mathrm{kGy}$ ), agreeing with the results obtained by Zanão et al. (2009), with a time decrease of 5.9 minutes to 5.2 minutes for the rice starch analyzed with doses up to $2 \mathrm{kGy}$. This event is correlated to the tendency of a gradual reduction of the maximum and final paste viscosity, with the elevation of the radiation doses.

Sung (2005) and Zanão et al. (2009), studying the effect of irradiation on the rice paste properties, observed that even low gamma radiation doses (up to $1.0 \mathrm{kGy}$ ) culminated in the modification of the starch microstructure, resulting in a significant paste viscosity reduction. According to Sung (2005), the storage can also reduce the rice paste viscosity and, thus, the reason that the food industry has a preference for using more "old" rice (less gimmy during cooking) to make rice derived products.

The break indicates the easiness with that the swollen granules disintegrate during the cooking (SIRISSONTARALAK; NOOMHORM, 2006). In the present research, the irradiated rice starch granules presented more susceptible to rupture (viscosity break) than the non-irradiated. That means that the starch granules of the irradiated rice became less stable to shearing. Zanão et al. (2009) also found higher viscosity break for the rice exposed to radiation (220 for the control and 440 for irradiated).

Another relevant alteration in this study was the decrease of the retrograde tendency for the rice starch granules submitted to radiation, which also agrees with the study of Zanão et al. (2009), who found a reduction of $59.5 \%$ in the tendency of the irradiated rice starch to retrograde. Knowing that the retrogradation can lead to the grain hardness increase due to the recrystallization of the starch macromolecules, the radiation treatment becomes interesting for the cooked refrigerated or frozen stored rice, because, the less retrogradation there is, the less product texture alteration.

According to Wu et al. (2002), the retrogradation parameter is frequently used as an indicator of the firmness of cooked rice. Higher values indicate firmer texture. As there was a reduction of the retrogradation tendency with the increase of the radiation dose, it is inferred that that processing modifies the texture of the cooked rice, making it softer.

\subsection{Polarized light microscopy}

Polarized light microscopy is widely used to determine the size, form and position of the starch hilum (JANE et al., 1994).

The photomicrographs for polished white rice starch evaluated in terms of doses of gamma irradiation, control (0kGy), $6.5 \mathrm{kGy}$ and $7.5 \mathrm{kGy}$ are shown in figure 3 .

It was verified that the birefringence remained in all of the whole starch granules, through the presence of a very defined and centered Maltese cross in the hilum (eccentric).

The starch granule is birefringent and, under polarized light, presents the typical Maltese cross. Knowing that the birefringence implies a high degree of molecular organization in the starch granules (JANE et al., 1994), the gamma radiation used in the present study, at the doses of $6.5 \mathrm{kGy}$ and $7.5 \mathrm{kGy}$, did not alter the microstruture of the polished white rice starch granules, contradicting Yu and Wang (2007) who observed alterations in the microstruture of the starch granules of this cereal, caused by the radiation.

Table 1 - Properties of polished white rice paste subjected to different doses of gamma radiation ( $0 \mathrm{kGy}, 6.5 \mathrm{kGy}$, and $7.5 \mathrm{kGy})$.

\begin{tabular}{lrrr}
\hline \multicolumn{1}{c}{ Parameters } & \multicolumn{3}{c}{ Average values * } \\
& Properties of polished white rice starch paste* \\
\hline Initial paste temperature $\left({ }^{\circ} \mathrm{C}\right)$ & $0 \mathrm{kGy}$ & $6.5 \mathrm{kGy}$ & $7.5 \mathrm{kGy}$ \\
Maximum viscosity $(\mathrm{RVU})$ & 83.32 & 84.96 & 85.41 \\
Viscosity break (RVU) & 2651.43 & 808.86 & 691.57 \\
Final viscosity (RVU) & 402.85 & 464.43 & 417.28 \\
Retrogradation tendency (RVU) & 5217.57 & 936.00 & 743.28 \\
Time to reach maximum viscosity (min) & 2969.00 & 591.57 & 469.00 \\
\hline
\end{tabular}




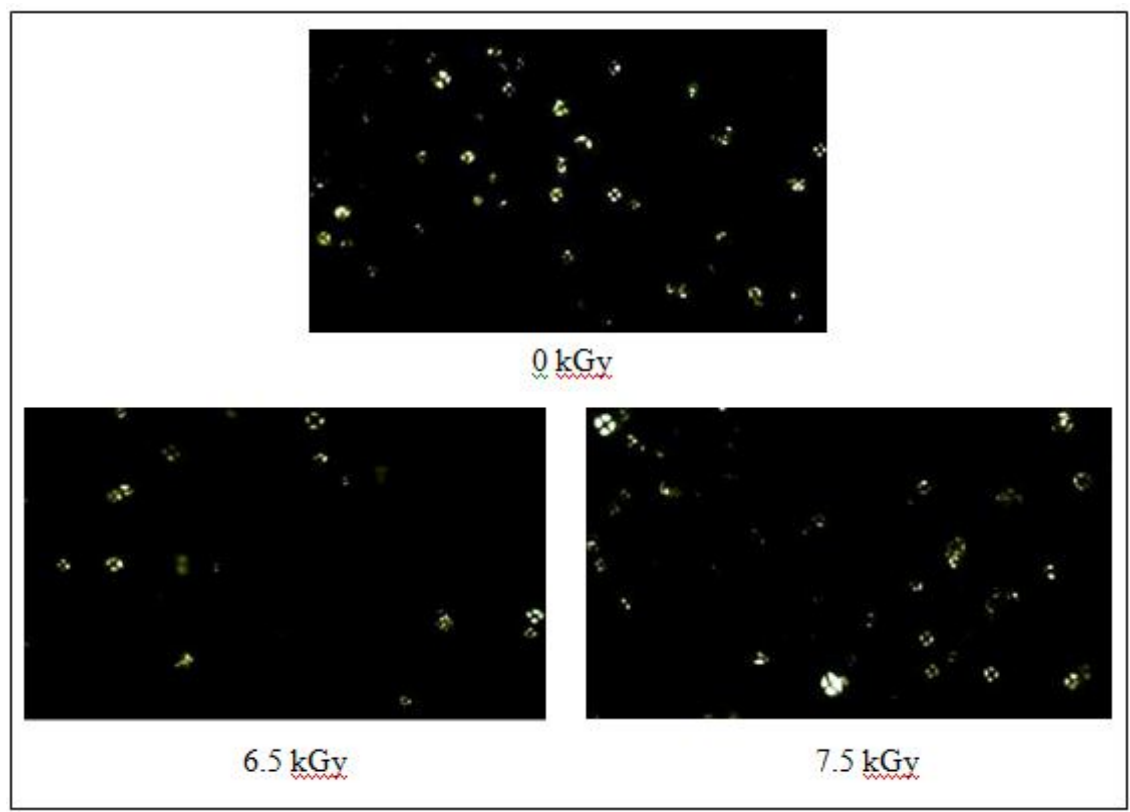

Figure 3 - Photomicrograph of rice starch granules not irradiated (0kGy) and irradiated with 6.5 kGy 7.5 kGy and observed under an optical microscope under polarized light (1000x).

\section{CONCLUSIONS}

According to the obtained results, it can be concluded that:

The free radicals produced during the irradiation process are no linger detected in the samples of irradiated polished white rice, after four months;

With the increase of the radiation doses, the profiles and property values of rice starch paste modify, a reduction of the maximum and final viscosity and a tendency towards retrogradation occur;

The microstruture of the rice starch granules is not affected due to gamma radiation, maintaining crystallinity and birefringence;

In spite of the irradiation having altered some characteristics of the polished white rice, it maintains similar properties to those mentioned in the literature as desirable for the quality of this cereal, not interfering, therefore, in the main decisive characteristics for product acceptability, besides contributing to the altering of its texture, making it softer.

\section{ACKNOWLEDGMENTS}

Magnetic Resonance Laboratory at UFMG and Soils Department at UFV for their assistance in conducting the analysis, especially to Dr. Klaus Wilhelm Heinrich Krambrock and Dr. Maurício Paulo Ferreira Fontes.

\section{REFERENCES}

AQUINO, S.; NUNES, T.C.F.; CORRÊA, B. Effect of gamma radiation on sensorial properties, water activity and rice mycobiota. ConScientiae Saúde, São Paulo, v.10, n.2, p. 215-222, 2011.

BAO, J.; BAO, Z.; JANE, J. Characterization of phyzical properties of flour and starch obtained from gammairradiated white rice. Starch \& Starke, Weinheim, v.57, p.480-487, 2005.

BASSINELLO, P.Z;; ROCHA, M.S.; COBUCCI, R.M.A. Avaliação de diferentes métodos de cocção de arroz de terras altas para teste sensorial. Santo Antônio de Goiás: Embrapa Arroz e Feijão, 2004, 8p.

BIANCHI, M.L.P.; ANTUNES, L.M.G. Radicais livres e os principais antioxidantes da dieta. Revista de Nutrição, Campinas, v.12, n.2, p. 123-130, 1999.

CHUNG, H,J.; LIU, Q. Molecular structure and physicochemical properties of potato and bean starches as affected by $\gamma$-irradiation. International Journal of Biological Macromolecules, Philadelphia, v.47, p. 214 222, 2010. 
DESROSIERS, M. Current status of the EPR method to detect irradiated food. Applied Radiation and Isotopes, Oxford, v.47, n.12, p.1621-1628, 1996.

\section{ELIASSON, A.C. Starch in food - Structure, function and} applications. New York: Boca Raton, CRC, 2004, 605p.

FRANCO, C.M. et al. Propriedades gerais do amido. Série cultura de tuberosas amiláceas latino americanas, São Paulo: Fundação Cargill, v.2, 2002.

GALLANT, D.J.; BOUCHET, B.; BADWIN, P.M.

Microscopy of starch: evidence of a new level of granule organization. Carbohydrate Polymers, Oxford, v.32, n.34, p.177-191, 1997.

HAN, J.A.; LIM, S.T. Effect of $\gamma$-irradiation on pasting and emulsification properties of octenyl succinylated rice starches. Carbohydrate Polymers, Oxford, p.1-24, 2012.

IMBERTY, A. et al. Recent advances in knowledge of starch structure. Starch/Starke, Stuttgart, v.43, n.10, p.375-384, 1991 .

JANE, J.L. et al. Anthology of starch granule morphology by scanning electron microscopy. Starch/ Starke, Stuttgart, v.46, n.4, p.121-129, 1994.

HANA, U. A; LIMB, S.T. Effect of irradiation on pasting and emulsiûcation properties of octenyl succinylated rice starches. Carbohydrate Polymers, Oxford, v. 90, p.1480-1485, 2012.

LEAL, A.S. et al. Ressonância paramagnética eletrônica RPE aplicada à análise de especiarias irradiadas (com radiação gama). Ciência e Tecnologia de Alimentos, Campinas, v.24, n.3, p.427-430, 2004.

LEE, J.; OH, S. et al. The effect of irradiation temperature on the non-enzymatic browing reaction in cooked rice.

Radiation Physics and Chemistry, Oxford, v.76, n.11/12, p.886-892, nov./dec. 2007.

LI, J.H.; VASANTHAN, T.; ROSSNAGEL, B.G Starch from hull-less barley: V. in - vitro susceptibility of waxy, normal and high amylose starches towards hydrolysis by alpha-amylases and amyloglucosidase. Food Chemistry, London, v.84, n.4, p.621-632, 2004.
LIU, Y.; YING MA, S.; XUE, J. S. Modifications of structure and physicochemical properties of maize starch by $\gamma$ irradiation treatments. Food Science and Technology, Oxford, v. 46, p. 156-163, 2012.

OATES, C.G. Towards and understanding of starch granule structure and hydrolysis. Trends in Food Science \& Technology, Cambridge, v.8, p.375-382, 1997.

R Development Core Team. R: a language and environment for statistical computing. Vienna: R Foundation for Statistical Computing, 2012.

SCHREIBER, G.A.; HELLE, N.; BÖGL, K.W. Detection of irradiated food methods and outine applications.

International Journal of Radiation Biology, London, v.6, n.1, p.105-130, 1993.

SIRISSONTARALAK, P.; NOOMHORM, A. Changes to physicochemical properties and aroma of irradiated rice. Journal of Stored Products Research, Oxford, v.42, n.3, p.264-276, 2006.

SUNG, W.C. Effect of gamma irradiation on rice and its food products. Radiation Physics and Chemistry, Oxford, v.73, n.4, p.224-228, 2005.

VITTI, P. A. Viscosidade do amido e sua importância nos alimentos. Boletim do Centro Tropical de Pesquisa e Tecnologia de Alimentos, Curitiba, n.8, p.69-83, 1996.

WU, D. et al. Effect of gama irradiation on starch viscosity and physicochemical properties of different rice. Radiation Physics and Chemistry, Oxford, v.65, n.1, p.29-86, 2002.

YU, Y.; WANG, J. Effect of $\gamma$-ray irradiation on starch granule structure and physicochemical properties of rice. Food Research International, Amsterdam, v.40, n.2, p.297-303, 2007.

ZANÃO, C.F.O. et al. Efeito da irradiação gama nas características físico-químicas e sensoriais do arroz (Oryza sativa L.) e no desenvolvimento de Sitophilus oryzae L. Ciência e Tecnologia de Alimentos, Campinas, v.29, n.1, p.46-55, mar. 2009. 